\title{
TINJAUAN YURIDIS NORMATIF PEMBERIAN HIBAH DAN \\ AKIBAT HUKUM PEMBATALAN SUATU HIBAH \\ MENURUT KOMPILASI HUKUM ISLAM ( KHI ) DAN KITAB UNDANG-UNDANG HUKUM PERDATA
}

\author{
Oleh : \\ Suisno \\ Dosen Fakutas Hukum Universitas Islam Lamongan
}

\begin{abstract}
ABSTRAK
Hukum sebagai kaidah atau norma sosial yang tidak terlepas dari nilai-nilai yang berlaku dalam masyarakat. Keluarga sebagai bagian dari masyarakat dapat memberikan suatu ajaran yang baik dalam hidup bermasyarakat. Salah satu permasalahan yang sering timbul adalah mengenai peralihan harta dari orang tua kepada anak-anaknya yang biasanya dalam bentuk hibah.Dalam prakteknya, banyak hibah yang diberikan kemudian dibatalkan oleh pemberi hibah dengan berbagai alasan, misalnya si penerima hibah berkelakuan buruk atau memiliki jiwa pemboros. Hal ini diketahui setelah hibah itu diberikan. Padahal orang itu sebelumnya menampakkan kelakuan baik namun kemudian berubah seiring perubahan waktu. Secara mendasar peneliti dalam penelitian ini menggunakan pendekatan undang-undang ( statute approach ) dengan menelaah Kitab Undang-undang Hukum Perdata dan Kompilasi Hukum Islam serta Peraturan Pemerintah Nomor 37 Tahun 1998 tentang peraturan jabatan Pejabat Pembuat Akta Tanah. Rumusan permasalahan yang dibahas oleh penulis adalah Pemberian Hibah dan Akibat Hukum Pembatalan Suatu Hibah Menurut Kompilasi Hukum Islam ( KHI ) dan Kitab Undang-undang Hukum Perdata ( KUHP ). Metode penelitian yang digunakan adalah yuridis Normatif dengan memberikan tujuan agar penulis maupun pembaca dapat mengetahui tentang pengaturan pemberian hibah dan akibat hukum pembatalan suatu hibah menurut Kompilasi Hukum Islam dan Kitab Undang-undang Hukum Perdata serta memberikan beberapa manfaat yaitu bagi pengembangan keilmuan dibidang hukum pada umumnya, serta memberikan kontribusi pemikiran dan pemahaman mengenai Pemberian hibah dan akibat hukum pembatalan suatu hibah.

Kata kunci : Tinjauan Yuridis normatif, Hubah ,Akibat huum, KHI, KUHPerdata.
\end{abstract}

\section{A. PENDAHULUAN}

Hukum sebagai kaidah atau norma sosial yang tidak terlepas dari nilai-nilai yang berlaku dalam masyarakat ${ }^{19}$. Keluarga sebagai bagian dari masyarakat dapat memberikan suatu ajaran yang baik dalam hidup bermasyarakat. Salah satu permasalahan yang sering timbul adalah mengenai peralihan harta dari orang tua kepada anak-anaknya yang biasanya dalam bentuk hibah. Dalam prakteknya, banyak hibah yang diberikan kemudian dibatalkan oleh

\footnotetext{
${ }^{19}$ Soerjono Soekanto, Pokok-pokok Sosiologi

Hukum, PT. RajaGrafindo Persada, Jakarta. 2007.
}

pemberi hibah dengan berbagai alasan, misalnya si penerima hibah berkelakuan buruk atau memiliki jiwa pemboros. Hal ini diketahui setelah hibah itu diberikan. Padahal orang itu sebelumnya menampakkan kelakuan baik namun kemudian berubah seiring perubahan waktu. Secara mendasar peneliti dalam penelitian ini menggunakan pendekatan undangundang ( statute approach ) dengan menelaah Kitab Undang-undang Hukum Perdata dan Kompilasi Hukum Islam serta Peraturan Pemerintah Nomor 37 Tahun 1998 tentang peraturan jabatan Pejabat Pembuat 
Akta Tanah. Rumusan permasalahan yang dibahas oleh penulis adalah Pemberian Hibah dan Akibat Hukum Pembatalan Suatu Hibah Menurut Kompilasi Hukum Islam (KHI) dan Kitab Undang-undang Hukum Perdata (KUHP). Metode penelitian yang digunakan adalah yuridis Normatif dengan memberikan tujuan agar penulis maupun pembaca dapat mengetahui tentang pengaturan pemberian hibah dan akibat hukum pembatalan suatu hibah menurut Kompilasi Hukum Islam dan Kitab Undang-undang Hukum Perdata serta memberikan beberapa manfaat yaitu bagi pengembangan keilmuan dibidang hukum pada umumnya, serta memberikan kontribusi pemikiran dan pemahaman mengenai Pemberian hibah dan akibat hukum pembatalan suatu hibah.

Hasil pembahasan menunjukkan bahwa tentang hibah dalam islam lebih bersifat tolong menolong ( ta'awun ) antar sesama, disebutkan dalam Qs. Al-Baqarah 2:262, Qs. AlMunafiqun 63:10 dan Qs. Al-Maidah ayat 2. Namun terdapat perbedaan pendapat mengenai ukuran pemberian hibah baik dari segi mazhab Hanafi maupun para ulama, oleh karena itu para umat islam mengambil keputusan ijma' yang telah di tentukan berdasarkan Kompilasi Hukum Islam dengan 1/3 ( sepertiga ) dari harta yang dimiliki untuk di hibahkan. Dengan mengacu syarat-syarat hibah dengan harus adanya pemberi hibah, adanya orang yang menerima hibah, adanya obyek hibah, adanya ijab kabul. Sedangkan dalam Kitab Undang-undang Hukum Perdata diatur dalam pasal 1666-1693.

Hibah merupakan perbuatan hukum pemindahan hak kepemilikan yang sengaja dialihkan kepada pihak lain. Ada beberapa bentuk perbuatan hukum pemindahan hak selain dilakukan dengan cara hibah, diantaranya jual beli, tukar menukar, pemberian menurut adat, pemasukan dalam perusahaan (inbreng) dan hibah wasiat (legaat). Pemindahan hak dilakukan pada waktu pemegang haknya masih hidup dan merupakan perbuatan hukum yang bersifat tunai, kecuali hibah wasiat ${ }^{20}$. Tunai berarti ketika dilakukannya perbuatan hukum tersebut, maka haknya telah berpindah kepada pihak lain.

Tentang hukumnya, bahwa kebolehan pembatalan kembali hibah dalam Pasal 1688 KUH Perdata. Dengan terjadinya pembatalan hibah ini, maka segala macam barang yang telah dihibahkan harus segera dikembalikan kepada penghibah dalam keadaan bersih dari bebanbeban yang melekat di atas barang tersebut. Pada dasarnya hibah dapat dilakukan secara lisan maupun tulisan seperti tertuang dalam Al-Qur'an Surat Al-Baqarah ayat 282 dan 283 sebagai dasar perjanjian dalam islam. Berkaitan dengan akibat hukum yang lahir dari hibah yang akan diberikan pada salah seorang ahli waris tanpa persetujuan ahli waris lainnya dan tidak dibuat secara otentik adalah dapat dibatalkan karena tidak ada persetujuan ahli waris lain dan menurut KHI pasal 210 ayat 2 barang siapa merasa haknya terlanggar maka dapat mengajukan gugatan pembatalan hibah di Pengadilan Agama.

Berdasarkan uraian tersebut diatas penulis untuk membahas tujuan penelitian sebagai berikut :

1. Untuk mengetahui pengaturan tentang pemberian hibah menurut Kompilasi Hukum Islam (KHI) dan kitab Undang-undang Hukum Perdata (KUHP).

2. Untuk mengetahui implikasi yuridis terhadap pembatalan

\footnotetext{
${ }^{20}$ Boedi Harsono, Hukum Agraria Indonesia (Sejarah Pembentukan Undang-Undang Pokok Agraria, Isi, dan Pelaksanaanya), Djambatan, Jakarta. 2008.
} 
pemberian hibah menurut Kompilasi Hukum Islam (KHI) dan kitab Undang-undang Hukum Perdata (KUHP).

\section{B. METODE PENELITIAN}

Tipe penelitian yang digunakan dalam penelitian ini adalah Penelitian Yuridis Normatif yaitu penelitian hukum kepustakaan. Yang pada penelitian hukum normatif, bahan pustaka merupakan data dasar yang dalam ilmu penelitian digolongkan sebagai data sekunder. Data Sekunder tersebut mempunyai ruang lingkup yang sangat luas, sehingga meliputi surat-surat pribadi, buku-buku harian, sampai dokumen-dokumen resmi yang dikeluarkan pemerintah. Adapun data sekunder tersebut memiliki ciri-ciri sebagai berikut, data sekunder pada umumnya ada dalam keadaan siap terbuat ( ready made), bentuk maupun isi data sekunder telah dibentuk dan diisi oleh peneliti-penelitih terdahulu, data sekunder dapat diperoleh tanpa terikat atau dibatasi tempat dan waktu.

Jenis pendekatan yang digunakan penulis adalah pendekatan perundangundangan ( statue approach ). Pendekatan ini dilakukan dengan cara melihat segala undang-undang dan regulasi terkait isu hukum yang sedang diteliti. Dalam pendekatan ini peneliti dapat melihat konsistensi antara regulasi satu dengan regulasi yang lainnya. Metode pendekatan perundang-undangan peneliti dapat melihat dasar filosofi atau dasar pemikiran mengapa peraturan tersebut dikeluarkan.

Pengumpulan bahan hukum dilakukan dengan mempergunakan bahan hukum primer, sekunder, dan tertier yaitu :

1. Bahan hukum primer

Bahan hukum primer yaitu bahan hukum yang diperoleh dari hukum positif atau peraturan perundangundangan.
2. Bahan hukum sekunder

Bahan hukum sekunder yaitu bahan hukum yang memberikan penjelasan mengenai bahan hukum primer yang terdiri dari, buku-buku yang membalas tentang hibah, artikel-artikel dan tulisan-tulisan yang berkaitan dengan masalah pembatalan hibah.

3. Bahan hukum tertier

Bahan hukum tertier adalah bahan hukum yang memberi petunjuk maupun penjelasan terhadap bahan hukum primer dan sekunder yang terdiri dari kamus, ensiklopedia dan hal lain yang bersangkutan dengan objek penelitian.

Dalam penulisan ini teknik analisa yang digunakan adalah deskriptif analisis yang berarti penulis dalam menganalisis berkeinginan untuk memberikan gambaran atau pemaparan atas subjek dan objek penelitian sebagaimana penilitian yang dilakukan.

\section{HASIL PENELITIAN DAN PEMBAHASAN \\ PENGATURAN PEMBERIAN HIBAH MENURUT KHI DAN KUH PERDATA}

\section{Hibah dalam perspektif hukum} islam

Apabila ditelusuri secara mendalam, istilah hibah itu berkonotasi memberikan hak milik oleh seseorang kepada orang lain tanpa mengharapkan imbalan dan jasa. Menghibahkan tidak sama artinya dengan menjual atau menyewakan. Oleh sebab itu, istilah balas jasa dan ganti rugi tidak berlaku dalam transaksi hibah. Berdasarkan hal itu, maka perlu lebih dahulu dikemukakan definisi atau pengertian hibah dalam pandangan ulama'. 


\section{Dasar Hukum Hibah}

Hibah merupakan suatu perjanjian yang bersifat timbal balik, karena hanya ada satu pihak yang wajib berprestasi dan pihak lainnya hanya mempunyai hak saja atas prestasi tersebut. Dalam Islam adanya hibah sangat dianjurkan mengingat lebih bersifat tolong menolong (ta'awun) antar sesama.

\section{Ukuran Harta Hibah yang} di Hibahkan

Terdapat perbedaan pendapat mengenai ukuran pemberian hibah, Sayyid Sabiq dan mengemukakan bahwa para ahli hukum Islam sepakat pendapatnya bahwa seseorang dapat menghibahkan semua hartanya kepada orang yang bukan ahli warisnya, hal yang sama dikemukakan oleh Eman Suparman, di dalam hukum Islam jumlah harta seseorang yang dapat dihibahkan itu tidak terbatas. Berbeda halnya dengan pemberian seseorang melalui wasiat yang terbatas pada sepertiga dari harta peninggalan yang bersih ${ }^{21}$.

Mengenai benda yang dihibahkan ini meliputi segala macam benda yang wujud atau tidak ada ditempat (al ma'dum). Prinsipnya, semua benda atau hak yang dapat diperjual belikan, maka dapat dihibahkan. Dalam konteks sekarang ini, seseorang mempunyai kekayaan bisa dalam berbentuk saham sebagai

\footnotetext{
${ }^{21}$ Eman Suparman, Hukum Waris Indonesia Dalam Prespektif Islam, Adat dan BW, Refika Aditama, Bandung, 2005.
}

surat bukti bahwa ia memiliki benda yang diterangkan dalam surat tersebut.

Ukuran harta atau benda yang dihibahkan, dalam Kompilasi Hukum Islam telah disebutkan dalam Pasal 210 bahwa :

"Orang yang telah berumur sekurang-kurangnya 21 tahun, berakal sehat dan tanpa adanya paksaan dapat menghibahkan sebanyak-banyaknya 1/3 (sepertiga) harta bendanya kepada orang lain atau lembaga".

\section{Rukun dan Syarat-Syarat Sah Hibah}

Kontrak hibah akan sempurna dengan adanya rukun dan syarat yang mencukupi ${ }^{22}$. Rukun dan syarat-syarat hibah terdiri atas :

a. Adanya orang yang menghibahkan atau pemberi hibah (penghibah) (al wahib).

b. Adanya orang yang menerima hibah (penerima hiba) (almahublah).

c. Adanya objek hibah, sesuatu yang dihibahkan (al-hibah)

d. Adanya ijab kabul (shighat hibah)

2. Pengaturan hibah berdasarkan kompilasi hukum islam (KHI)

Sebagaimana telah diuraikan bahwa hibah, merupakan pemberian dari seorang pemberi hibah kepada orang lain sebagai penerima hibah ketika si pemberi hibah (yang punya harta) masih hidup, sedangkan warisan diberikan ketika si pewaris (yang

\footnotetext{
${ }^{22}$ Abdul Halim Muhammad, Undang-Undang Muamalat dan Aplikasinya Kepada Produk-Produk Perbankan Islam.
} 
punya harta) telah meninggal

dunia. Walaupun waktu pemberiannya berbeda itu diberikan kepada anak atau ahli waris karena akan menentukan terhadap bagian warisan yang akan diterimanya.

Apabila hibah itu diperhitungkan sebagai warisan, sangat tergantung pada kesepakatan anak-anaknya, atau diperhitungkan menurut system kewarisan. Karena seperti kata Umar Bin Al-Khattab, perdamaian justru lebih baik, dari pada nantinya harus melibatkan pengadilan. Kedua, pabila pemberian itu dinyatakan sebagai hibah saja, maka menurut petunjuk Rasulullah SAW. Maka pembagiannya harus rata. Ini ditegaskan oleh tindakan nabi, "jika anak-anakmu yang tidak engkau beri dengan pemberian yang sama, maka tarik kembali.

3. Pengaturan hibah berdasarkan KUH Perdata

Dalam KUH Perdata memuat substansi hukum penghibahan yang terdiri dari 4 bagian berisi Pasal 1666-1693. Bagian-bagian tersebut yaitu:

1) Pada bagian pertama memuat ketentuan-ketentuan umum yang terdiri dari pengertian tentang penghibahan, penghibahan yang dilakukan oleh orang hidup,barang penghibahan, syahnya penghibahan dan syaratsyarat penghibah

2) Pada bagian kedua memuat tentang kemampuan untuk memberikan dan menerima hibah yang berisi tentang orang-orang yang berhak memberikan dan menerima hibah dan penghibahan suami istri.
3) Bagian ketiga memuat cara menghibahkan sesuatu yang berisi tentang pembuatan akta hibah pada notaris, hibah kepada wanita dan kepada anak-anak dibawah umur.

4) Bagian keempat memuat tentang pencabutan dan pembatalan hibah yang berisi tentang syarat-syarat pencabutan dan pembatalan suatu hibah. ${ }^{23}$

IMPLIKASI

YURIDIS

PEMBATALAN

HIBAH

MENURUT KOMPILASI HUKUM

ISLAM (KHI) DAN KITAB

UNDANG-UNDANG HUKUM PERDATA (KUHP)

1. Pembatalan hibah menurut kompilasi hukum islam (KHI)

Menurut Pasal 212 Kompilasi

Hukum Islam menyatakan, bahwa hibah tidak dapat ditarik kembali, kecuali hibah orang tua kepada anaknya. Pembatalan atau penarikan kembali atas suatu pemberian (hibah) merupakan perbuatan yang diharamkan, meskipun hibah tersebut terjadi antara dua orang yang bersaudara atau suami isteri. Adapun hibah yang boleh ditarik kembali hanyalah hibah yang dilakukan atau diberikan orang tua kepada anaknya.

Menarik kembali hibah hukumnya haram, kecuali hibah yang diberikan oleh seorang ayah kepada anaknya. Hal ini berdasarkn dalil Hadist yang diriwayatkan Hadist Shahih Muslim yang berbunyi : "Ibnu Abbas berkata bahwa Nabi SAW bersabda : orang yang mengambil semula pemberiannya umpama orang yang menelan semula muntahnya".

\footnotetext{
${ }^{23}$ Kitab Undang-Undang Hukum Perdata, hal 446
} 
2. Pembatalan hibah menurut Kitab Undang-undang hukum perdata

Menurut Kitab UndangUndang Hukum Perdata, tidak ada ketentuan yang memberikan pembatasan tentang hibah yang diberikan si pemberi hibah sebagaimana yang diatur dalam Kompilasi Hukum Islam. Pada prinsipnya hibah yang telah diberikan oleh seseorang kepada orang lain tidak dapat ditarik kembali atau dibatalkan, kecuali dalam hal-hal sebagaimana yang diatur dalam Pasal 1688 KUH Perdata yaitu :

1) Jika syarat-syarat penghibaan itu tidak dipenuhi oleh penerima hibah. Dalam hal ini barang yang dihibahkan tetap tinggal pada penghibah, atau ia boleh meminta kembali barang itu, bebas dari semua beban dan hipotek yang mungkin diletakkan atas barang itu oleh penerima hibah serta hasil dan buah yang telah dinikmati oleh penerima hibah sejak ia alpa dalam memenuhi syaratsyarat penghibahan itu. Dalam hal demikian penghibah boleh menjalankan hak-haknya terhadap pihak ketiga yang memegang barang tak bergerak yang telah dihibahkan sebagaimana terhadap penerima hibah sendiri.

2) Jika orang yang diberi hibah bersalah dengan melakukan atau ikut melakukan suatu usaha pembunuhan atau suatu kejahatan lain atas diri penghibah.

3) Jika penghibah jatuh miskin sedang yang diberi hibah menolak untuk memberi nafkah kepadanya.
3. Akibat hukum hibah yang tidak dibuat secara otentik tanpa persetujuan ahli waris lain

1. Akibat Hukum Hibah yang dibuat secara otentik

Berdasarkan

KUHPerdata pelaksanaan hibah harus dilakukan dengan akta Notaris kecuali pemberian hadiah dari tangan ke tangan secara langsung. Jika hibah dibuat dengan akta otentik maka akibat hukumnya hibah yang dibuat tersebut menjadi sebagai alat bukti tertulis yang memiliki nilai pembuktian yang sempurna yang harus dilihat apa adanya, tidak perlu dinilai atau ditafsirkan lain, selain yang tertulis dalam akta hibah tersebut, karena telah dibuat dalam bentuk yang sudah ditentukan oleh Undangundang sesuai Pasal 38 UUJN.

2. Akibat hukum hibah yang dibuat tidak secara otentik tanpa persetujuan ahli waris lainnya.

Penghibahan untuk barang tidak bergerak seperti tanah dan bangunan yang dilakukan oleh para pihak dengan tidak menggunakan akta otentik maka keabsahan penghibahan itu tidak sah karena hibah harus dibuat dalam akta otentik, tidak bisa dibuat dalam akta di bawah tangan. ${ }^{24}$ Jika pemberian hibah dilakukan dengan surat dibawah tangan, maka hibah peralihan hak kepemilikan secara yuridis tersebut baru berlaku saat sudah dibuat suatu Akta Hibah di hadapan

\footnotetext{
${ }^{24}$ Pasal 1682 KUH Perdata
} 
Notaris / PPAT yang berwenang.

Jika hibah dibuat tanpa menggunakan akta otentik dan tanpa persetujuan ahli waris maka ketika ahli waris yang tidak menyetujui akta hibah tersebut dengan tidak menggunakan akta otentik tersebut tidak mengikat para pihak lagi.

\section{PENUTUP}

\section{Kesimpulan}

Pada dasarnya hibah dapat dilakukan secara lisan maupun tulisan seperti tertuang di dalam Al-Qu'an Surat Al-Baqarah ayat 282 dan 283 sebagai dasar dari perjanjian dalam Islam, berdasarkan hal tersebut maka jika hibah dilaksanakan secara lisan/tidak dibuat secara tertulis dengan akta otentik, hal ini bukan berarti perbuatan hibah tersebut tidak sah. Berkaitan dengan akibat hukum yang lahir dari hibah yang akan diberikan pada salah seorang ahli waris tanpa persetujuan ahli waris lainnya dan tidak dibuat secara otentik adalah dapat dibatalkan karena tidak ada persetujuan dari ahli waris lain, dan jika hibah tersebut melebihi $1 / 3$ bagian dari harta warisan. Hal ini sesuai dengan ketentuan Pasal 210 ayat (2) KHI selanjutnya jika salah satu ahli waris merasa terlanggar haknya, maka dapat mengajukan gugatan pembatalan hibah tersebut ke Pengadilan Agama.

\section{Saran}

Disarankan pada masyarakat yang ingin menghibahkan hartanya terutama benda tidak bergerak agar membuatnya dalam bentuk akta otentik. Hal ini dikarenakan akta otentik merupakan suatu alat pembuktian apabila suatu saat nanti terjadi sengketa, dan tidak menggunakan akta yang dilakukan dibawah tangan karena tidak adanya kekuatan hukum yang mengikat dan bagi Notaris harus memperhatikan ahli waris jika memang yang di hibahkan dalam bentuk waris, dan setelah membacakan akta harus menanyakan kembali kepada para penghadap, jika menjawab benar. Maka lepaslah tanggung jawab Notaris karena Notaris hanya bertanggung jawab atas formil atas materi akta.

\section{E. DAFTAR PUSTAKA}

Abdul Halim Muhammad, UndangUndang Muamalat dan Aplikasinya Kepada ProdukProduk Perbankan Islam.

Abdurrahman, Kompilasi Hukum Islam, Akademika Pressindo, Jakarta, 2010.

Ahmad Rofiq, Hukum Islam Di Indonesia, PT. Jakarta Raja Grafindo Persada, Jakarta. 1998

Al-Ustadz Muhammad Thalib, AlQur'anul Karim Tarjamah Tafsiriyah, CV. Qolam Mas, 2012.

Boedi Harsono, Hukum Agraria Indonesia (Sejarah Pembentukan Undang-Undang Pokok Agraria, Isi, Dan Pelaksanaannya), Djambatan, Jakarta.2008.

Eman Suparman, Hukum Waris Indonesia dalam Prespektif Islam, Adat dan BW, Refika Aditama, Bandung, 2005. 